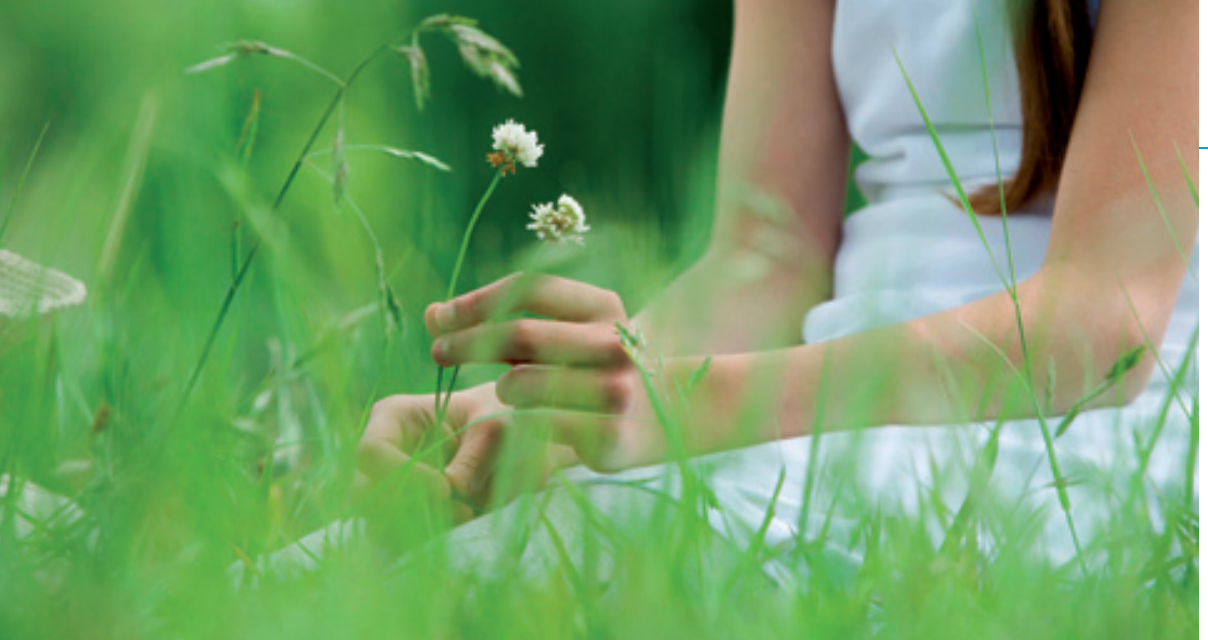

\title{
Tidlig menarke gir nedsatt lungefunksjon som voksen
}

\section{Kvinner med tidlig menarke har dårligere lungefunksjon og mer astmasymptomer enn andre.}

Hormonell og metabolsk status påvirker lungehelse hos kvinner. Enkelte studier har vist at tidlig menarke er en risikofaktor for astma, brystkreft, diabetes og hjerte- og karsykdom.

I studien European Community Health Survey II ble 3354 kvinner fra 21 sentre i Europa, bl.a. fra Haukeland universitetssykehus, undersøkt. Kvinner med tidlig første menstruasjon hadde nedsatt lungefunksjon og mer astmasymptomer i voksen alder enn de øvrige. Kvinner med menarke $\leq 10$ år gamle hadde lavere forsert ekspiratorisk volum etter ett sekund $\left(\mathrm{FEV}_{1}\right)$, lavere forsert vitalkapasitet (FVK), lavere $\mathrm{FEV}_{1}$ i prosent av forventet og lavere FVK i prosent av forventet enn dem som var 13 år ved menarke. Kvinner med tidlig menarke hadde mer astmasymptomer (OR 1,80), astma med bronkial hyperreaktivitet (OR 2,79) og høyere astmaskår.

Resultatene støtter hypotesen om at utviklingsmessige, metabolske og hormonelle faktorer spiller en rolle i utviklingen av lungesykdommer. Både lav fødselsvekt, overvekt i oppveksten, metabolsk syndrom og endokrine forstyrrelser kan spille inn.

Sammenhengen mellom tidlig menarke og økte astmasymptomer er vist også tidligere. Det nye i denne studien er at kvinnene hadde nedsatt lungefunksjon også i prosent av forventede lungefunksjonsverdier. Tidlig menarke bør vurderes som en risikofaktor for astma og lungehelse.

\section{Ferenc Macsali}

ferenc.macsali@med.uib.no

Kvinneklinikken

Haukeland universitetssykehus

\section{Litteratur}

1. Macsali F, Real FG, Plana E et al. Early age at menarche, lung function, and adult asthma. Am J Respir Crit Care Med 2011; 183: 8-14.

\section{Hyppigheten av influensavaksinasjon kan økes}

Postkort og telefonoppringning er effektivt for å få flere til å vaksinere seg mot influensa (Cochrane Database Syst Rev 2010; nr. 9: CD005188).

Oversikten omfattet 44 randomiserte, kontrollerte studier med eldre mennesker i i-land. Der var stor heterogenitet blant studiene - i kun fem studier var det lav risiko for skjevhet og i seks var risikoen moderat. Det var bare disse studiene som det ble trukket konklusjoner fra.

I tre studier ble den enkleste intervensjonen undersøkt, nemlig personlige postkort, og her viste alle studiene effekt. I tre studier undersøkte man effekten av å minne leger om vaksinasjon, men ingen viste effekt. Det var ingen studier som omhandlet intervensjoner på samfunnsnivå, f.eks. politiske beslutninger eller det å betale helsepersonell for å nå et vaksinasjonsmål.

\section{Karbamazepin gir moderat økt risiko for ryggmargsbrokk}

Eksponering for karbamazepin i første trimester $ø$ ker risikoen for alvorlige medfødte misdannelser. Nå har en internasjonal forskergruppe undersøkt hvilke spesifikke misdannelser som er assosiert med karbamazepinbruk (BMJ 2010; 341: c6581).

En litteraturgjennomgang ga en prevalens av alvorlig medfødt misdannelse på $3,3 \%$ etter eksponering for karbamazepin i første trimester og identifiserte fem alvorlige medfødte misdannelser. I en pasientkontroll-studie med over 3,8 millioner fødsler fant forskerne at ryggmargsbrokk var signifikant assosiert med eksponering for karbamazepinmonoterapi, sammenliknet med ingen bruk av antiepileptika. Men risikoen var signifikant lavere enn for valproat. Økt risiko for de andre fire misdannelsene ble ikke bekreftet i datamaterialet.

\section{Koloskopi gir lavere risiko for tarmkreft}

\section{Tykktarmskreft var sjeldnere hos personer over 50 år som var blitt undersøkt med koloskopi de siste ti årene enn hos dem som ikke var det.}

Mye tyder på at koloskopi kan forebygge tarmkreft ved å påvise og fjerne tarmpolypper som er forstadier til kreft. I en tysk pasient-kontroll-studie ble 1688 personer over 50 år med påvist kreft i tykktarmen (inkludert rectum) sammenliknet med 1932 kontrollpersoner uten slik kreft (1). Koloskopi utført de siste ti år var assosiert med en $77 \%$ reduksjon i risikoen for tykktarmskreft: oddsratio justert for flere kjente risikofaktorer var 0,23 (95\% KI 0,19-0,27). Tilsvarende oddsratio for kreft i høyre og venstre del av tykktarmen var henholdsvis $0,44(0,35-0,55)$ og $0,16(0,12-0,20)$.

- En pasient-kontroll-studie som denne har lavere utsagnskraft enn en prospektiv, randomisert studie, sier professor Geir Hoff ved Sykehuset Telemark. - Både seleksjonsskjevhet og konfunderende faktorer kan ha påvirket resultatene. Flere andre studier har de siste årene ikke kunnet påvise noen sikker beskyttelse mot tykktarmskreft ved koloskopi - spesielt ikke mot kreft i øvre del av tykktarmen, mens denne studien tyder på beskyttelse mot kreft i alle deler av tykktarmen.

Bare randomiserte screeningsstudier i utvalgte alderskohorter kan si noe sikrere om nytten av koloskopi av friske personer. Flere slike studier er i gang, sier Hoff, som leder en studie med deltakelse fra flere land, blant annet Norge.

\section{Petter Gjersvik}

petjense@online.no

Tidsskriftet

Litteratur

1. Brenner H, Chang-Claude J, Seiler CM et al. Protection from colorectal cancer after colonoscopy: a population-based, case-control study. Ann Intern Med 2011: 154: 22-30. 